\title{
GLOBALIZATION AS A CHALLENGE TO UKRAINIAN EXPORTERS OF IRON ORE RAW MATERIAL
}

\author{
Olha Hrybinenko', Svitlana Shahoian² \\ State Higher Educational Institution "National Mining University", Ukraine
}

\begin{abstract}
The purpose of the article - to identify the main characteristics of iron ore mining and beneficiation enterprises that allow carrying out income-generating export activity in terms of increasing the level of globalization of the country. Methodology. Information background of the research consists of publications of KOF rating of the level of globalization of countries of the world (1991-2016), annual reports of the United States Geological Survey (1995-2016), statistical data of the State Statistics Service of Ukraine (2012-2016), scientific publications and findings of experts of the national and world markets for iron ore. Achieving the purpose of this article provides for the following stages and methods of scientific research: time series analysis - for evaluating dynamics of globalization index for Ukraine, dynamics of global iron ore production and export of iron ore raw material by Ukrainian producers; vertical analysis - for determining the structure of global iron ore production; methods of qualitative analysis (expert estimation) - for defining characteristics of mining and beneficiation enterprises that allow ensuring competitiveness in the global market; generalization - for determining options of sales of Ukrainian iron ore production in international markets in terms of globalization. Results. High-level globalization of Ukraine makes it significantly dependent on the condition of global markets of key export branches of the national economy. Ukraine belongs to the top ten countries with the largest reserves of iron ore and its production in the world; however, an insignificant part of the market doesn't allow influencing its condition. The surplus of iron ore and deficit of iron-ore pellets in the global market stimulate the interest of Ukrainian mining and beneficiation enterprises in projects on improving their existing production facilities. The volatility of the global market for iron ore raw material increases the level of financial and investment risks. Practical significance. The established trends in globalization of Ukraine and the status of Ukrainian producers of iron ore raw material in the global market allow us more thoroughly analyse their competitive advantages in the long view and develop risk reduction programs. Alternatives to sales of Ukrainian iron ore production of vertically-integrated holding under globalization are made. Value/originality. Determined advantages of Ukrainian exporters of iron ore raw material in the global market that, in terms of high-level globalization of the country, are provided by the corporate synergy of the transnational vertically-integrated exporting company.
\end{abstract}

Key words: globalization, iron ore global market, export of iron ore raw material, transnational companies, international mining and smelting holding, export strategy in terms of globalization.

JEL Classification: F15, F23, L61, L72

\section{Introduction}

Globalization as a basic process and phenomenon that characterises the contemporary development of the world economy causes not only the revival of international trade, it also promotes a deeper level of integration of international economies, their interdependence, creation and implementation of common interests, conflict generation, other worldwide phenomena. Global rating and level of development of countries depend on many factors that both government agencies and economic entities should take into account in determining their own strategies in the globalized world.

Considerable volume of exports of goods and services, leadership in innovation, high level of population wellbeing, and other indicators of countries of $\mathrm{G} 7$ prove that economic development of a separate country, increase in revenues of its enterprises and citizen income are possible upon condition ofintensive use of opportunities of the global market and world economy. The openness

Corresponding author:

${ }^{1}$ Department Economic of Enterprise, State Higher Educational Institution "National Mining University".

E-mail: hrybinenko.o.m@nmu.one

${ }^{2}$ Department of Economics of Enterprises, State Higher Educational Institution "National Mining University".

E-mail:shahoian.s.m@nmu.one 
of the national economy arising from the international integration of the country has both positive and negative sides, which is determined by export assets of the country and required import. As a large by population size, territory, and natural resources European country, Ukraine makes considerable political and legislative efforts for the formation of a stable basis of economic activity of national enterprises in leading markets of the world. Conclusion of the association agreement with the European Union, free trade agreements with Canada, Georgia, and other countries, simplification of cargo customs clearance procedures, switch to international accounting standards, improvement of state regulatory bodies and other measures form international prospects for Ukrainian business, however, contribute to the improvement of its dependence on the world market condition. Due to this, national enterprises should consider international trends; this considerablyincreases the level of complexity of business environment analysis and forecasting, development of business strategies, assessment of investment attractiveness of projects.

Exports of goods/services to other countries of the world have always been a source of incomes for Ukraine. A feature of Ukrainian exports was its structure, namely, a high share of production of mining and metals sector (MMS) that for a long time formed up to $60 \%$ of annual inflow of foreign currency in Ukraine. In 2015-2017, the share of MMS gradually decreased to $20 \%$ at the expense of a dynamic increase in exports of products of the agroindustrial complex (AIC). Such a change in the structure of export revenues of the country was determined not only by improving competitive advantages of AIC enterprises and demand for their production but also deterioration of the economic situation in the world market of mineral resources, for example, iron ore raw material (IORM). As a result, it increased risks to export strategies of Ukrainian companies of mining and metals sector, which in some periods led to losses, termination of production development investment programs. The other side of national producers' access to foreign markets is the increase in the level of the national market openness, in particular, in terms of imports of iron ore raw material. Given the above, relevant is the issue of assessing development prospects of iron ore mining and beneficiation enterprises in the conditions of strengthening the processes of globalization.

\section{Analysis of recent research and publications}

Prospects of iron ore mining and beneficiation enterprises of Ukraine in internal and external markets, features of innovative development, and strategic issues in the field of production, marketing, corporate finance are considered in works of many Ukrainian and foreign scientists. For example, issues of mining and metals sector of Ukraine formed as a result of slowdown of the growth of world market for ferrous metals are studied by S. Kulytskyi (Kulytskyi, 2015), focusing attention on strategies of owners of iron ore enterprises regarding their provision of financial sustainability and investment in projects that will ensure reduction of production expenses. Assessing export orientation of Ukrainian iron ore enterprises, I. Savchuk (Savchuk, 2017) stresses that it becomes impossible to increase steel production and rolling necessary for the needs of the military-industrial complex of Ukraine.

Features of the methodology for evaluating the level of countries' globalization, as well as dynamics of the globalization of Ukraine and its nearest neighbour countries, are studied by N.P. Stuchynska (Stuchynska, 2017). T.V. Zlunitsyna (Zlunitsyna, 2016) notes the negative influence of the extensive use of powerful iron ore reserves in Ukraine on its specialization in the international division of labour and concludes about state strategy on activity in the internal market for iron ore production. According to M.V. Kyryku (Kyryku, 2016), international integration of Ukraine should be accompanied by system government measures on promoting innovation and investment security of MMS enterprises, in particular, management of real investment volumes and $\mathrm{R} \& \mathrm{D}$ financing processes, the attraction of foreign direct investment in the industry.

Studying the influence of marketing concepts on the formation of development strategies of iron ore enterprises in terms of globalization, V.M. Tkach (Tkach, 2015) notes a significant dependence of production development projects on characteristics of a mined deposit, impossibility of rapid manoeuvring the range of marketable products, long-term depreciation of fixed assets value, etc. In the context of obtaining competitive advantages, L. Horoshkova (Horoshkova, 2014) proves the expediency of vertical integration of MMS enterprises given the positive forecasts of an increase of prices for IORM, coal, electricity tariffs. Lowering of transaction costs and reduction of indirect taxation of intermediate products became the basis for these conclusions, which is important in view of high resource and energy intensity of steel production and risks of decreasing competitive advantages of the national metallurgy in the global market in terms of approaching raw material and energy prices to the world level and strengthening competitive pressure on the part of newly-introduced facilities. D.A. Dovhan (Dovhan, 2016) stresses on the formation of a new, cluster structure of the national mining and metals sector based on innovation improvement of their production, the relevance of expansion of national product consumption, consolidation processes in the industry. In the issue of Ukrainian export promotion, it is important to achieve the highest quality of export, which is evaluated by indicators of its concentration and diversification. T.O. Vlasiuk (Vlasiuk, 2015) proves a considerable gap between Ukrainian export indicators and those of developed countries, which indicates a focused specialization of the country. 
Summing up the directions of scientific research, we note that the vast majority of authors are of the opinion about the presence of interest of different subjects in solving strategic issues of international integration of Ukraine into the world economy and the need to coordinate concepts of national, branch, and microeconomic development with the consideration of capacity of iron ore mining industry of Ukraine. Thus, issues of economic security of mining and beneficiation enterprises taking into account the orientation of state export strategy towards more knowledge-intensive industries require constant attention. In particular, insufficient attention is paid to the identification of characteristics of mining and beneficiation enterprises that allow them to maintain profitability in terms of volatility of the world market for iron ore material.

\section{The purpose and methodology of research}

The purpose of the article - to identify the main characteristics of iron ore mining and beneficiation enterprises that allow carrying out income-generating export activity in terms of increasing the level of globalization of the country. Achieving the purpose of this research provides for the following stages: assessment of the level of globalization of Ukraine; appraisal of iron ore reserves and trends in the world market for iron ore raw material; evaluation of dynamics of Ukrainian production and export of iron ore raw material; identification of the main characteristics of Ukrainian iron ore mining and beneficiation enterprises that determine prospects for their activity in terms of globalization.

For solving the tasks of the study, the following methods of scientific research are used: time series analysis - for evaluating dynamics of globalization index for Ukraine, dynamics of global iron ore production and export of iron ore raw material by Ukrainian producers; vertical analysis - for determining the structure of global iron ore production; methods of qualitative analysis (expert estimation) - for defining characteristics of mining and beneficiation enterprises that allow ensuring competitiveness in the global market; generalization for determining options of sales of Ukrainian iron ore production in international markets in terms of globalization.

\section{The level of globalization of Ukraine}

Influence of global markets on the national economy of a separate country is determined by volume, structure, geography, level of concentration of its export, and many other indicators of foreign economic activity of subjects of the national business. The level, conditions, ways of international integration of the country within internationalization, transnationalization, and globalization processes occupy an important place. Evaluation of globalization level for 207 countries of the world is provided by KOF Globalization Index, according to which Ukraine ranks among top 100 of the most globalized countries. In the period of 1991-2016, the mentioned globalization index of Ukraine increased in 2.4 times (from 29.97 to 70.71), and in 2017 somewhat decreased to 70.24 (Fig. 1). As a comparison, the Netherlands has the highest globalization index 97.29, and the Channel Islands are characterized with the lowest one - 1.0 (KOF Swiss Economic Institute, 2017). The level of globalization of a country is calculated by indicators of economic, social, and political spheres, each of which can be a catalyser of a deeper international integration of this country. The most developed key factor of globalization in Ukraine is its political sphere, which is strengthened by the orientation of Ukraine's strategy towards European integration, encouragement of export initiatives of enterprises, etc. The most dynamic key factor of the globalization of Ukraine is its economic sphere, which index for the period of 2001-2016 increased from 49.73 to 68.89 (+38.5\%).

Economic globalization is evaluated by commodity flow, services of capital, as well as corresponding

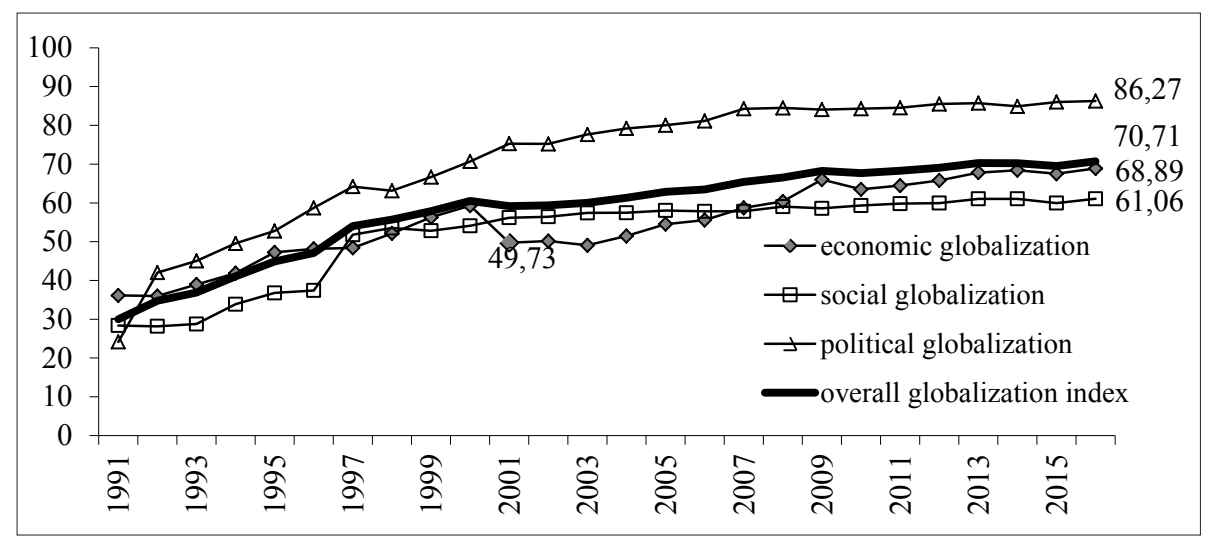

Fig. 1. The level of globalization of Ukraine according to KOF Globalization Index

Compiled by the author according to data (KOF Swiss Economic Institute, 2017, long) 
restrictions, in particular, customs tariffs, taxes, hidden barriers, control over the capital movements. Australia, Brazil, and China, as the largest countries that produce IORM, have overall globalization indexes of $90.05,61.4$, and 62.02 respectively, which speaks about different state strategies on integration to the world economy. For example, political globalization of China is evaluated by the index of 84.26, and economic and social globalization -52.84 and 54.23 respectively, thus, the supply of products to the market of China will require meeting specific requirements, rules, adaptation to the culture of business partners. In this context, an increase of social globalization of Ukraine, which assesses qualitative and quantitative characteristics of global communications, the convergence of national cultures, becomes relevant.

Thus, due to globalization, complex direct and mediated relations regarding movements of capital, people, technology, commodities, ideas, etc. are created. In the aspect of results of activity of iron ore mining and beneficiation enterprises, these aspects of globalization determine requirements to the quality of production, conditions of supply, possibilities of entrance to international markets and competition with
IORM producers from other countries of the world, opportunities to attract foreign capital, control activities of national producers through companies with foreign registration, optimize product supply logistics, etc.

\section{Dynamics and structure of global iron ore production}

Scales of production activity of national companies, quality of mineral reserves in the country, cost of other factors of production, prices of transportation companies, state customs policy, and other factors make an influence on the attractiveness of IORM product supply in the world market and in the market of a separate importing country.

Iron ore production (concentrate, pellets, agglomerate) is conducted by many countries of the world, and Ukraine, having the fourth largest reserve of these mineral resources, is ranked among the top 10 of the largest countries that produce IORM. The volume of global iron ore production is characterized by a general increasing trend since 2001, however, in 2015-2016, a decrease in the mentioned volumes is observed (Fig. 2). A general cause for this is a fluctuation of global GDP,

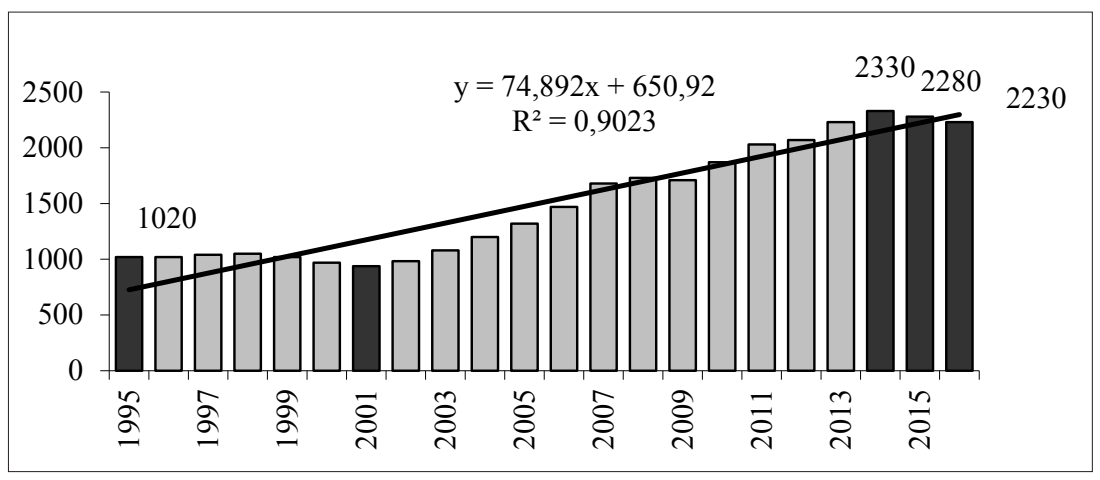

Fig. 2. Iron ore statistics: world production, million metric tons

Compiled by the author according to data (Mining engineering, 2017; USGS Mineral Resources Program, 2016; USGS Mineral Resources Program, 2017)

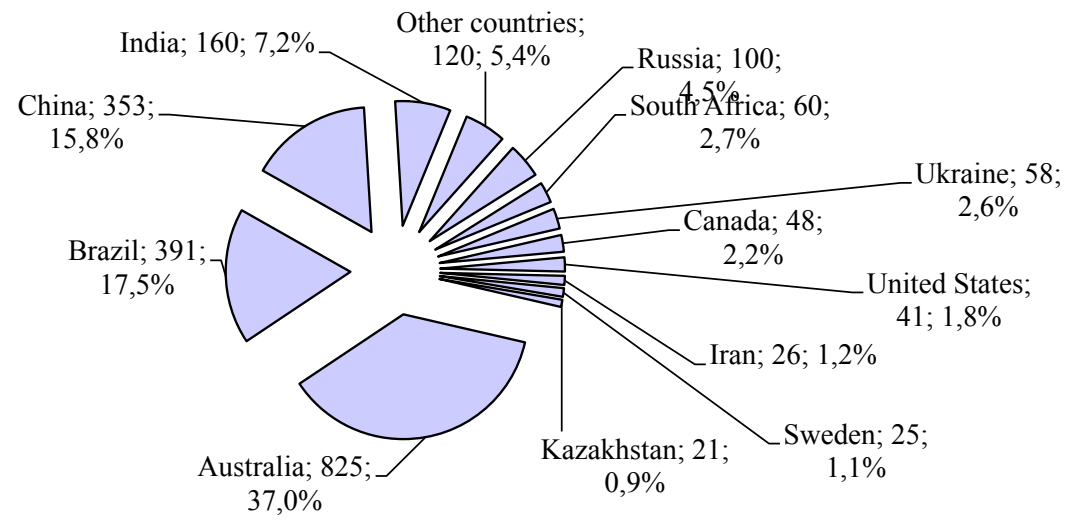

Fig. 3. Structure of global iron ore production in 2016, million metric tons; \%

Compiled by the author according to data of the United States Geological Survey (USGS Mineral Resources Program, 2017) 
a specific cause - deterioration in demand for IORM. For example, slowdown in GDP growth of PRC (the biggest world importer of IORM), its state strategy on the development of own iron ore deposits force exporters of IORM to diversify international product sales markets and to cut down prices $(2015,40$ \$ $/ \mathrm{MT}$, CFR China contract, 62\% Fe (UNCTAD, 2017). In contrast, plans of government regarding concessional lending for construction and business encouragement for ensuring higher GDP growth rates contribute to price raising (2016, 84 \$ / MT, CFR China contract, 62\% $\mathrm{Fe}$ (UNCTAD, 2017). In 2016, China imported over 1000 million tons of iron ore at the cost of 93 billion USD, where 640 million tons - ore from Australia, and 215 million tons - ore from Brazil.

The share of Ukraine in global iron ore production in comparison with leaders is low (Australia, Brazil, PRC) and undergoes fluctuations, for example, it was $2.0 \%$ in 2014 , in $2015-2.9 \%$, in $2016-2.6 \%$ (Fig. 3 ).

The presented state of Ukrainian producers of IORM doesn't allow influencing the market, which determines their potential strategic actions: to reduce production cost, to curtail export, to get state support, to search for other foreign markets, etc.

\section{Export of Ukrainian IORM in terms of globalization}

Export of iron ore raw material (IORM) by Ukrainian producers in the period of 2012-2014 increased annually in natural units, but the decline in demand and lower prices in the world market of IORM have determined the downward trend in export revenues (Fig. 4).

The most successful for Ukrainian exporters of IORM was 2013 ( 3.74 billion USD), and the worst result, almost twice as low, was observed in 2016 ( 1.83 billion USD). In 2013-2014, an increase in export volumes provided lower cash inflows. In 2016, export of iron ore raw material was $5 \%$ of the export value of Ukraine as a whole. The constancy of the downward trend in export revenues is confirmed by high (significant) determination coefficient $\mathrm{R} 2=0.67$. Consequently, the maintenance of export revenues at an attractive level for enterprises is ensured by an increase in the volume of export of products in kind. It updates for mining and beneficiation enterprises the issue of preparing new fields for development, but the national legislative regulation of land relations significantly complicates the process of siting of new land plots.

According to expert estimates of specialists of the analytical department of the State Enterprise "Ukrainian Industrial External Expertize," investment company "Investment Capital Ukraine" (ICU), the surplus of iron ore in the world market is 20-50 million tons (Yvanova, 2016). According to Ingrid McMahon, manager of the investor and communications department, Ferrexpo, which controls the activity of iron ore MCC in the Poltava region, there is a shortage of iron ore pellets. The increase in the demand of metallurgical enterprises for pellets is compounded by the technological catastrophe and the downfall of the Brazilian manufacturer Samarco, an increase in the environmental requirements of the Chinese government to its own producers of iron ore agglomerate. A significant aspect of developing a commodity strategy is the difference in the price of pellets from the price of lump ore, which increases the attractiveness of investment in projects for improving the enriching cycle (Interfax-Ukraine, 06.07.2017 12:25).

It should be noted that iron ore, which does not require enrichment, is extracted by Zaporizhzhia Iron Ore Company in Ukraine. Other mining and beneficiation enterprises in Poltava and Dnipropetrovsk regions of Ukraine enrich the extracted ore as a result of the low content of iron in the ore, their commodity products are iron ore concentrate and agglomerate, pellets. The volume

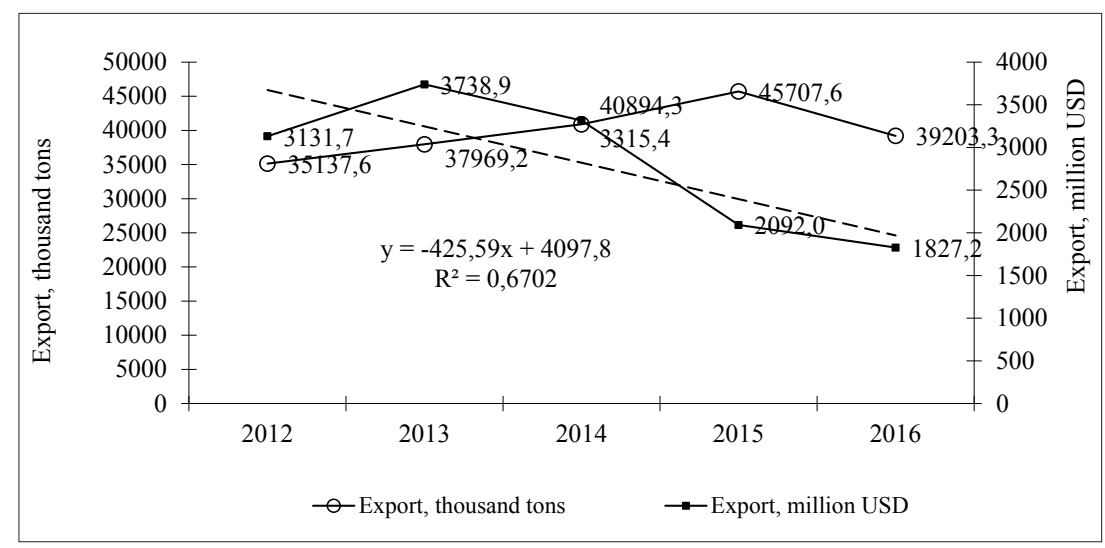

Fig. 4. Dynamics of export of iron ore raw material (IORM) by Ukrainian enterprises in 2012-2016

Compiled by the author according to data of the State Statistics Service of Ukraine 
of investments that can direct enterprises to the development of production capacity will depend, first of all, on the ability to accumulate the relevant financial resource, the forecast of the world market, prospects of the domestic Ukrainian market as an alternative to international markets. It is the domestic market that allowed Metinvest Holding (Metinvest Holding, 2017), which controls the activities of three Kryvyi Rih iron ore plants, to secure the sale of their products due to the presence of associated metallurgical plants in the holding's structure. Consequently, in addition to gaining a certain competitive position in the world market, national producers of iron ore raw materials should maintain a status quo in the domestic market.

Staying in the mining and processing enterprises as a part of a vertically-integrated holding can be understood as a factor in the economic security of the plant (Shahoian \& Hrybinenko, 2017). This is confirmed not only by the supply of the plant's production for metallurgical enterprises of the holding in Ukraine but also by facilitating access to the markets of North America, Europe, South-East Asia. In particular, there are used professional services of the freight forwarding company associated with the holding, long-term agreements with the stevedoring company, which carries out ore handling in ports.

Together with the Ukrmetaluhprom association of enterprises, the problems of non-compliance by PJSC "Ukrzaliznytsia" with contracts for the transportation of iron ore raw materials to European countries are solved (Censor.NET, 12.12.17 14:41). According to O. Kalenkov, the chairman of Ukrmetalurhrom, in November 2017, the average level of provision of MMS enterprises by open wagons was $29 \%$, resulting in over
300 thousand tons of IORM, which led to the creation of the surplus stock of commodity products, lack of export earnings.

Consolidation of the assets of the mining and smelting metals sector of Ukraine through the formation of vertically integrated structures for gaining competitive advantages should be considered in the context of strategies for increasing the profitability of products that are closest to the final consumption. It is a metallurgical product in the mining and smelting holding and, therefore, the activity of extractive enterprises can depend substantially on the prospects of metallurgical enterprises in international markets and the domestic market (Fig. 5). For example, the director of sales of Metinvest D. Nikolaienko noted that the loss of control over the metallurgical enterprises of the holding (Alchevsk Iron \& Steel Work, Yenakiieve Iron and Steel Works, Donetsksteel) in the occupied eastern territories of Ukraine led to directing iron ore raw materials to the PRC market (Interfax-Ukraine, 24.04.2017 15:34). Consequently, the optimization of processes and reduction of mining and concentrating enterprises' costs, originating due to corporate synergy (Shahoian, Solodovnyk \& Chernenko, 2016), has an inverted negative effect.

The development of Ukrainian iron ore plants is appropriate to determine, taking into account trends in specialized and related world markets (metal), but also to assess the markets for metal products and machinery, trends in the national energy market, in particular, the coal industry (Pashkevych, 2011). This choice correlates with the state export strategy of Ukraine (Government portal, 27.12.2017 12:48), in which the emphasis is placed on strengthening the support for mechanical engineering enterprises, which will increase

Global environment

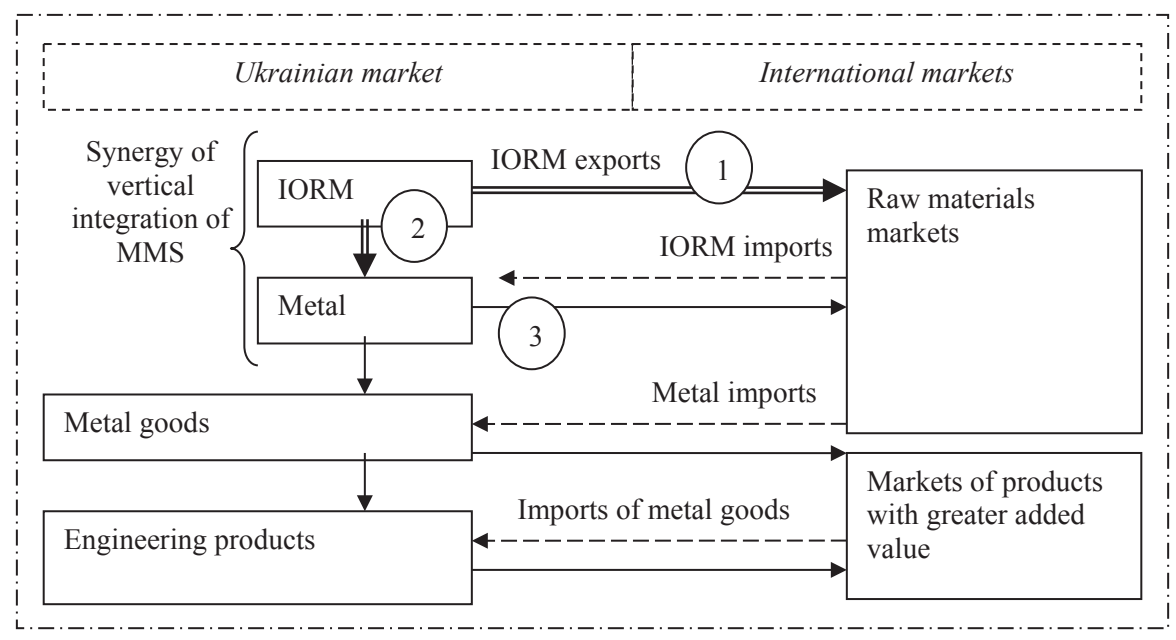

Fig. 5. Alternatives of sales of Ukrainian iron ore products of vertically-integrated holding in terms of globalization: 1 - exports of IORM by mining and concentrating enterprises; 2 - sales of IORM to metallurgical enterprises of the holding in the domestic market; 3 - exports of products of metallurgical enterprises of the holding 
the demand for the products of the mining and metals sector. Realization of this approach is possible in the conditions of stimulating the domestic demand for metal and metal products for construction, development of machines and mechanisms, which, in the conditions of innovation and competitiveness of the latter, will allow the suppliers of raw materials - enterprises of MMS to obtain significant positive economic results in the conditions of globalization.

\section{Conclusions}

High-level globalization of Ukraine makes it significantly dependent on the condition of global markets of key export branches of the national economy. Ukraine belongs to the top ten countries with the largest reserves of iron ore and its production in the world; however, an insignificant part of the market doesn't allow influencing its condition. The surplus of iron ore and deficit of iron-ore pellets in the global market stimulate the interest of Ukrainian mining and beneficiation enterprises in projects on improving their existing production facilities. The volatility of the global market for iron ore raw materials increases the level of financial and investment risks. The strategy of protecting the economic interests of the mining and beneficiation enterprise can be built taking into account the corporate synergy provided by a vertically-integrated holding transnational company.

Search for opportunities to reduce the cost of iron ore products, assessment of advantages and risks of vertical integration, and forecasting of the effectiveness of state measures regarding the development of the domestic market, Ukrainian industries potentially competitive in the global market, are considered as a direction for further research.

\section{References:}

Censor.NET (12.12.17 14:41) «Ukrmetalurhprom» - Hroismanu: Priorytety UZ povynni buty spriamovani na zabezpechennia rozshyrennia ekonomichnoho zrostannia v Ukraini, a ne v RF ["Ukrmetalurhprom" - to Hroisman: The priorities of the Ukrzaliznytsia should be aimed at ensuring the expansion of economic growth in Ukraine, and not in the RF]. Available at: https://ua.censor.net.ua/n3038887 (accessed 15 December 2017).

Dovhan D.A. (2016) Konkurentospromozhnist vitchyznianoho eksportu produktsii chornoi metalurhii na svitovomu rynku [Competitiveness of the domestic export of ferrous metallurgy products in the world market] International Humanitarian University Herald. Series: Economics and Management, vol. 17, pp. 17-20. Available at: http://vestnik-econom.mgu.od.ua/journal/2016/17-2016/6.pdf (accessed 05 December 2017).

Mining engineering (2017) Global iron ore production data; Clarification of reporting from the USGS. Available at: https://minerals.usgs.gov/minerals/pubs/commodity/iron_ore/global_iron_ore_data.pdf (accessed 02 December 2017).

Government portal (27.12.2017 12:48) Uriad skhvalyv Eksportnu stratehiiu Ukrainy na naiblyzhchi 4 roky [The Government approved the Export Strategy of Ukraine for the next 4 years]. Available at: https://www.kmu.gov.ua/ ua/news/uryad-shvaliv-eksportnu-strategiyu-ukrayini-na-najblizhchi-4-roki (accessed 30 December 2017).

Horoshkova L. (2014) Komplimentarnyi pidkhid pry formuvanni stratehii haluzei natsionalnoho hospodarstva [The complementary approach in forming the strategies of branches of the national economy] Economics and management organization, vol. 3-4, pp. 312-318. Available at: http://jeou.donnu.edu.ua/article/view/1129/1148 (accessed 16 December 2017).

KOF Swiss Economic Institute (2017) KOF Globalisation Index. Globalization-2017(long). Available at: http:// globalization.kof.ethz.ch/media/filer_public/2017/04/19/globalization_2017_long.xlsx (accessed 30 December 2017).

KOF Swiss Economic Institute (2017) KOF Globalisation Index. Rankings-2017. Available at: http://globalization. kof.ethz.ch/media/filer_public/2017/04/19/rankings_2017.pdf (accessed 30 December 2017).

Kulytskyi S. (2015) Problemy rozvytku ukrainskoho hirnycho-metalurhiinoho kompleksu na suchasnomu etapi [Problems of development of Ukrainian mining and metals sector at the present stage]. Ukraine: events, facts, comments, no. 15, pp. 41-62. Available at: http://nbuviap.gov.ua/images/ukraine/2015/ukr15.pdf (accessed 16 December 2017).

Kyryku M.V. (2016) Derzhavne rehuliuvannia innovatsiinoho rozvytku zalizorudnoi haluzi Ukrainy [State regulation of innovative development of the iron ore industry of Ukraine] (PhD Thesis), Kryvyi Rih: SHEI "Kryvyi Rih National University”. Available at: http://www.kntu.kr.ua/doc/K_23_073_03/Kiriku_dis.pdf (accessed 16 December 2017).

Metinvest Holding, LLC (2017) Richni zvity [Annual reports]. Available at: https://www.metinvestholding.com/ ua/investors/reports (accessed 20 December 2017).

Pashkevych M.S. (2011) Dyversyfikatsiia diialnosti vuhledobuvnykh pidpryiemstv v konteksti rozvytku depresyvnykh rehioniv Ukrainy [Diversification of activities of coal mining enterprises in the context of the development of depressed regions of Ukraine] Economic Bulletin of the National Mining University, no. 3, pp. 11-17.

Savchuk I. (2017) Eksport zalizorudnoi syrovyny z Ukrainy [Export of iron ore from Ukraine]. Herald of Taras Shevchenko National University of Kyiv. Special Military Sciences, vol. 1, pp. 37-41. Available at: http://nbuv.gov. ua/UJRN/VKNU_vsn_2017_1_10 (accessed 16 December 2017). 
Shahoian S.M. \& Hrybinenko O.M. (2017) Sutnist ta shliakhy zabezpechennia ekonomichnoi bezpeky pidpryiemstva [Essence and ways of ensuring the economic security of the enterprise] Scientific Herald of Kherson State University. Series: Economic Sciences, vol. 1, no. 22, pp. 98-100.

Shahoian S.M., Solodovnyk L.M. \& Chernenko N.O. (2016) Otsinka vplyvu korporatyvnoi synerhii ta kompleksnoho vykorystannia syrovyny na ekonomiku asotsiiovanoho hirnycho-zbahachuvalnoho pidpryiemstva [Assessment of the impact of corporate synergy and integrated use of raw materials on the economy of an associated mining and concentrating enterprise] Economic Bulletin of National Technical University of Ukraine "Kyiv Polytechnic Institute", no. 13, pp. 253-259. Available at: http://ev.fmm.kpi.ua/article/viewFile/80120/75676 (accessed 16 December 2017).

Stuchynska N.P. (2017) Riven hlobalizatsii: kilkisne obgruntuvannia yakisnykh transformatsii [The level of globalization: quantitative justification for qualitative transformations]. Investments: Practice and Experience, no 10, pp. 100-105. Available at: http://www.investplan.com.ua/pdf/10_2017/22.pdf (accessed 18 December 2017). Tkach V.M. (2015) Osoblyvosti formuvannia stratehii rozvytku zalizorudnykh pidpryiemstv Ukrainy na zasadakh marketynhu v umovakh hlobalizatsii [Features of forming the strategy of development of iron ore enterprises of Ukraine on marketing principles in terms of globalization] Economics and Entrepreneurship, no. 35-34, pp. 297311. Available at: http://ir.kneu.edu.ua/bitstream/2010/19285/1/297-311.pdf (accessed 20 November 2017).

Interfax-Ukraine (06.07.2017 12:25) Ynterviu menedzhera po rabote s ynvestoramy y kommunykatsyiam kompanyy Ferrexpo Ynhryd MakMэkhon (Ingrid McMahon) ahentstvu "Ynterfaks-Ukrayna" [Interview with the manager for work with investors and communications of Ferrexpo company Ingrid McMahon to the agency "Interfax-Ukraine"]. Available at: http://interfax.com.ua/news/interview/434132.html (accessed 04 October 2017).

Interfax-Ukraine (24.04.2017 15:34) Pislia zupynennia metpidpryiemstv na NKT "Metinvest" perenapravyv velyki obsiahy ZRS u Kytai - dyrektor iz prodazhu [After stopping the metallurgical enterprises on TUT, Metinvest redirected large volumes of IORM to China - sales director] Available at: http://ua.interfax.com.ua/news/ general/417564.html (accessed 12 may 2017).

UNCTAD (2017) The Iron Ore Market 2017" by The United Nations Conference on Trade and Development. Available at: http://unctad.org/Sections/ditc_commb/docs/suc2017_IronOre_Flyer_en.pdf (accessed 17 December 2017).

USGS Mineral Resources Program (2016) Mineral commodity summaries 2016 (iron ore). Available at: https:// minerals.usgs.gov/minerals/pubs/commodity/iron_ore/mcs-2016-feore.pdf (accessed 17 December 2017).

USGS Mineral Resources Program (2017) Mineral commodity summaries 2017 (iron ore). Available at: https:// minerals.usgs.gov/minerals/pubs/commodity/iron_ore/mcs-2017-feore.pdf (accessed 17 December 2017).

Vlasiuk T.O. (2015) Stan i tendentsii zovnishnotorhovelnoi diialnosti Ukrainy: vyklyky dlia ekonomichnoi bezpeky ta sposoby yikh podolannia [The state and tendencies of Ukraine's foreign trade activity: challenges to economic security and ways to overcome them] Strategic Priorities, no. 4 (37), pp. 48-58. Available at: http://sp.niss.gov.ua/ content/articles/files/6-1457000439.pdf (accessed 17 December 2017).

Yvanova T. Eksport zhelezorudnoho syria yz Ukrayny obrechen na padenye (2016) [Export of iron ore from Ukraine is doomed to fall] Business Paper "Hubs", 07.11.2016 11:18. Available at: http://hubs.ua/economy/ eksport-zhelezorudnogo-sy-r-ya-iz-ukrainy-obrechen-na-padenie-94773.html (accessed 06 May 2017).

Zlunitsyna T.V. (2016) Perspektyvy vitchyznianykh vydobuvnykh pidpryiemstv na mizhnarodnykh rynkakh zalizorudnoi produktsii [Prospects of domestic extractive enterprises in international markets for iron ore products] Globalization Challenges in XXI Century: Socio-Economic Strategy of Ukraine's Revival (Ukraine, Kyiv, May 24, 2016) (EIC A.A. Mazaraki), Kyiv: Kyiv National University of Trade and Economics, pp. 67-69. Available at: https: //knteu.kiev.ua/file/MTc=/4acce37697b365e48a541750d9eb47d1.pdf (accessed 06 May 2017). 